\title{
CONGRESSIONAL POWER TO ENFORCE THE FOURTEENTH AMENDMENT AGAINST PRIVATE ACTS
}

\author{
LAURENT B. FRANTZ $†$
}

Fourteenth Amendment

Sec. 1. All persons born or naturalized in the United States, and subject to the jurisdiction thereof, are citizens of the United States and of the State wherein they reside. No State shall make or enforce any law which shall abridge the privileges or immunities of citizens of the United States; nor shall any State deprive any person of life, liberty, or property, without due process of law; nor deny to any person within its jurisdiction the equal protection of the laws.

Sec. 5. The Congress shall have power to enforce, by appropriate legislation, the provisions of this article.

It is generally believed that the subject of this article does not exist, since Congress cannot enforce the fourteenth amendment against private acts, but only against "state action." This is supposed to have been the constitutional result of the Supreme Court decisions of the 1870's and 1880's invalidating much of the civil rights legislation of the Reconstruction period. In particular, the Cruikshank, ${ }^{1}$ Harris, $^{2}$ and Civil Rights ${ }^{3}$ cases are supposed to have laid down the unqualified rule that if federal civil rights legislation is directed at merely "private acts" it must be denounced as unauthorized by the fourteenth amendment, and hence as unconstitutional unless some alternative constitutional authority for it can be established. Yet the consensus is almost as general that, whatever the original understanding may have been ${ }^{4}$ as to the new

$\dagger$ Editor, Bancroft-Whitney Co., San Francisco. During the early stages of the germination of the theory expressed in this article, the writer benefited greatly from the criticisms, suggestions, and friendly encouragement of the late Professor Douglas B. Maggs of Duke University Law School.

1. United States v. Cruikshank, 92 U.S. 542 (1876).

2. United States v. Harris, 106 U.S. 629 (1883).

3. Civil Rights Cases, 109 U.S. 3 (1883).

4. No detailed review of the original understanding will be attempted here. It is believed that none is necessary, since this is oft-plowed ground. See, for example: FLACK. The Adoftion of the Fourteenth Amendarent (1908); Kendrick, Journal of the Jornt Comartitee of Fifteen on Reconstruction (1914); tenBroek, The Antislavery Origins of the Fourteenth Amendment (1951); James, The Framing of the Fourteenth Amendment (1956); Harris, The Quest for Equality (1960); 2 Crosskey, Politics and the Constitution 1083-1118 (1953) ; Boudin, Truth and Fiction about the Fourteenth Amendment, 16 N.Y.U. L.Q. 19 (1938); Graham, The "Conspiracy Theory" of the Fourteenth Amendment, 47 YaLE L.J. 371, 48 Yale L.J. 171 (1938); Fairman, Does the Fourteenth Amendment Incorporate the Bill of Rights? The Original Understanding, 2 Stan. L. Rev. 5 (1949); Frank \& Munro, The Original Understanding of "Equal Protection of the Lawe", 50 CoLuM. L. Rev. 131 (1950); Graham, The Early Antislavery Background of the Fourteenth Amendment, 1950 WIs. L. REv. 479 \& 610 (1950) ; Crosskey, Charles Fairman, "Legislative History," and the Constitutional Limitations or State Authority, 22 U. CHI. L. Rev. 1 (1954); Fairman, A Reply to Professor Crosskey, 22 U. CEI. L. REv. 144 (1954); Graham, Our "Declaratory" Foutrteenth Amendinent, 7 STAN. L. REv. 3 (1954); Bickel, The Original Understanding and the Segregation Decision, 69 HARV. L. REV. 1 (1955). 
legislative powers being conferred on the Congress, ${ }^{5}$ it certainly did not correspond to this state-action-only formula. ${ }^{6}$ Even those who have defended the formula have generally been content to do so on policy grounds without venturing to claim that it is an accurate, or even tenable, reading of the original intent. ${ }^{7}$ The latter position would be a difficult one to defend, in the light of the historical context.

As the Supreme Court has itself pointed out, ${ }^{8}$ one of the most significant clues to the original understanding is the situation which the amendment was designed to remedy. That situation is described at length and in detail in the testimony on conditions in the South taken by the Joint Committee on Reconstruction, ${ }^{9}$ the committee which drafted the fourteenth amendment and proposed it to the Congress. This testimony does refer here and there to instances of discriminatory state legislation, actual or threatened, ${ }^{10}$ and more frequently to abuse of power by state officials. ${ }^{11}$ But it requires no more than a glance at the testimony in order to see that "state action" in this sense, while it may have had some effect on the flavor of the stew, is very far from being its principal ingredient. The principal ingredient is a pervasive pattern of private wrongs, motivated by popular prejudice and hostility, directed against Negroes primarily ${ }^{12}$ and to a lesser, but significant, degree against Northern whites ${ }^{13}$ and against those Southern whites who had been disloyal to their states by being loyal to the Union. ${ }^{14}$ If the orthodox theory of the fourteenth amendment is correct, then the committee which studied the situation and attempted to draft a constitutional remedy for it came up with a

5. Most studies of the original understanding have concentrated almost exclusively on its meaning as a self-executing provision to be applied by courts, with little attention to the question of what legislative powers were intended to be conferred on the Congress. Flack, however, is a conspicuous exception to this statement. tenBroek and Harris also devote more than the usual amount of attention to the latter question.

6. See, e.g., FlACK, op. cit. supra note 4, at 277; TENBROEK, op. cit. supra note 4, at 97-98; HARRIS, op. cit. supra note 4, at 53.

7. See, e.g., Samuel Shellabarger's memorial address on Chief Justice Waite, 126 U.S. 585, 600-01 (Appendix) (1888).

8. Maxwell v. Dow, 176 U.S. 581, 601-02 (1900). 1866).

9. Report of the JoInt Commitite on Reconstruction (Gov't Printing Office,

10. See, e.g., id., pt. II at 106,107 ; pt. II at $218,245,269$; pt. III at $13,25,31,61,68$, $133,144,184 ;$ pt. IV at 10.

11. See, e.g., $i d$., pt. I at 51 ; pt. II at $6,7,17,31,51,110,143,145,175,178,180,184$, 197, 208 et seq., 215, 216, 229, 269; pt. III at 12, 14, 46, 47, 62, 105, 123, 139, 168 et seq.; pt. IV at 53, 54, 75, 79, 80, 126, 142, $155,159$.

12. See, e.g., id., pt. I at 108,121 ; pt. II at $2,6,17,53,55,127,153,170$ et seq., 175 , 183, 184, 187, 196, 197, 199, 206, 208 et seq., 218, 222 et seq., 269, 334 et seq.; pt. III at $3,5,7,8,10,17,31,37,42,62,78,104,119,141,142,143,146$ et seq., 149, 150, 168 et seq., $173,184,185$; pt. IV at $3,9,36$ et seq., $39,46,47,48,49$ et seq., $63,64,65,75,81,83,88$, $125,146,153$.

13. See, e.g., id., pt. II at 43,47, 110, 171, 179, 207, 208 et seq., 269; pt. III at 19 et seq., 70, 78, 142, 143, 151; pt. IV at 4, 8, 37, 53, 55, 67, 73, 79, 81, 151, 152, 153.

14. See, e.g., id., pt. II at $6,17,43,47,110,171,187,207$; pt. III at $7,61,70,78,142$, 168 et seq.; pt. IV at 48, 60, 66, 73, 152. 
solution which wholly failed to relate to the main body of the problem. When the testimony is examined more closely, it becomes apparent that the great bulk of it deals with injustices which are not only "private acts," but acts which would violate any state's ordinary laws against homicide and assault and battery. And the aspect of the matter which justifies bringing it to national attention, and which is felt as requiring a national remedy, is not the nature, severity, nor even the frequency of these acts, but the fact that the ex-Confederate states, though they have laws against homicide and assault and battery, and though they enforce those laws in general, cannot or will not enforce them in this particular connection. The situation is summed up in the testimony of a Freedmen's Bureau Agent:

Of the thousand cases of murder, robbery, and maltreatment of freedmen that have come before me, and of the very many cases of similar treatment of Union citizens in North Carolina, I have never yet known a single case in which the local authorities or police or citizens made any attempt or exhibited any inclination to redress any of these wrongs or to protect such persons .... That seems to me the worst indication of the state of society there-worse than the fact that these things take place. ${ }^{15}$

The evidence taken by the Joint Committee, together with its report and recommendations, was printed in 150,000 copies for distribution by Congress, and excerpts from it, as it was given from day to day, were published and commented upon in the Northern press. ${ }^{16}$ Thus, when the Republican Party presented itself to the electorate in 1866 with the fourteenth amendment and the Civil Rights Bill as its platform, it was with the testimony taken by the Joint Committee as the factual basis to explain and justify those pieces of legislation. This being the case, it is reasonable to infer that not only in the Congress, but in the ratifying legislatures and amongst the voters who elected the ratifying legislatures, the fourteenth amendment was widely thought of as something which would empower the Congress to deal effectively with the situation depicted in the testimony. ${ }^{17}$

15. Id., pt. II at 209.

16. KENDRICK, op. cit. sitpra note 4 , at 265 .

17. The existence of such a situation and the need to extend national protection to persons not being adequately protected by the states was a continuing theme of the 39th Congress, as well as of the Joint Committee testimony. The Schurz and Grant reports on conditions in the South, though differing widely on their estimates of the situation, had agreed on the need for protecting the freedmen against private persecution, as well as official oppression. TENBROEK, op. cit. supra note 4, at 164 . The bill to enlarge the powers of the Freedmen's Bureau, the first measure which the 39th Congress considered to deal with the situation, would have made it the duty of the President "to extend military protection" whenever certain rights enjoyed by white persons were refused to Negroes "in consequence of any State or local law, ordinance, police, or other regulation, custom, or prejudice...." [emphasis added]. Quoted in Bickel, supra note 4, at 8. In support of the bill, Senator Trumbull repeatedly spoke of the need to protect the freedmen against "public sentiment." HARRIs, op. cit. supra note 4, at 31-32 (1960). Even before the fourteenth amendment had been proposed for ratification, both this bill and the Civil Rights Bill were defended by assertions that Congress had the power and duty to extend national protection 
Furthermore, the framers and backers of the fourteenth amendment were primarily interested in enlarging the powers of the Congress, not those of the federal judiciary, ${ }^{18}$ which was looked upon with considerable distrust. It is almost impossible to imagine that a group motivated by this objective would have considered acceptable, as a definition of the new powers to be conferred, one couched in terms only of acts of state aggression. They could not have thought that it would often be appropriate to restrain a state's legislative or judicial acts otherwise than by an appeal to the federal judiciary. A "state action" concept of congressional enforcement power is almost automatically limited to punishing abuses of power by state officials; even here, it can operate only in very extreme instances, since it could seldom be appropriate, or even practical, for Congress to prescribe in detail the duties and functions of state officials. So the traditional "state action" interpretation pulls inevitably toward producing an amendment which confers new power primarily on the federal judiciary, while granting only minimal power to the Congress. A proposal with this built-in tendency (which would have been apparent at the time had contemporaries read the language as it is now usually read) would certainly not have been satisfactory to the framers and backers of the fourteenth amendment. Furthermore, the central problem with which they were attempting to deal - a pervasive pattern of private wrongs sheltered by state in-

to the freedmen if the states failed to protect them. FLACK, op. cit. supra note 4, at 11-54; TENBROEK, op. cit. supra note 4, at 156-80; HARRIS, op. cit. supra note 4, at 24-32.

It is also important to note that, whether the abolitionist background of the fourteenth amendment was as decisive as Graham and tenBroek have contended, it is not possible to doubt, in the light of their studies, that it was of very great importance. Those Congressmen who had abolitionist backgrounds were in an excellent position to appreciate the problem which can be presented by a combination of mass private hostility and state failure to protect. The abolitionist movement had itself suffered from such a combination, in the North as well as the South. Graham, supra note 4, at 479, 610; TENBroEK, op. cit. supra note 4, at 11-12.

It is not surprising that members of Congress with abolitionist backgrounds stressed the duty of all governments to protect persons in the enjoyment of all their rights. The Abolitionists were driven from the South, and because of lack of governmental protection they were subjected to varying degrees of violence in the North, including murder and the destruction of printing presses.

HARRIs, op. cit. supra note 4, at 30 n.15 (emphasis added).

18. [A] majority of the members of these Congresses regarded Congress as the primary organ for the implementation of the guarantees of privileges and immunities, due process, and equal protection: This does not mean that the Radical Republicans intended to preclude judicial action to apply provisions condemning discrimination by their own force; they did not. However, the Radicals did not trust the judiciary in general and the Supreme Court in particular, either before or after the passage of the resolution submitting the proposed amendment to the states.

Id. at 53-54.

It should be noted that decisions of courts had not normally favored abolitionists before the war. There was consequently little inclination to bestow new powers on the judiciary, but rather to lean on an augmented power of Congress, if it could be controlled.

JARIES, op. cit. supra note 4, at 184. 
action - is one which congressional power cannot reach at all, unless Congress can deal with the private acts directly. For Congress to command the states to give better and more even-handed enforcement to their homicide and assault and battery laws, and to punish the states if they failed to do so, would be a most cumbersome mode of operating.

And indeed for the first seven years after the fourteenth amendment was ratified, Congress believed it possessed, and actually exercised a power to protect the newly-freed Negro from private aggression, as well as from "state action." During this period it enacted three statutes intended in whole or in part to enforce the amendment. The first two undertook, among other things, to punish conspiracies by two or more persons to prevent any citizen from enjoying any right or privilege granted or secured to him by the federal Constitution or laws ${ }^{10}$ or to deprive any person or class of persons of the equal protection of the laws. ${ }^{20}$ The third prohibited racial discrimination in access to inns, public conveyances, and places of public amusement. ${ }^{21}$ The three implementing statutes were sponsored and enacted by the same group in Congress, and to a large extent by the same individuals, as the amendment itself. ${ }^{22}$ They therefore amount to an almost contemporaneous construction of the amendment by its authors.

Finally, the framers wrote in the light of apparently settled constitutional doctrine that the mere recognition of a right in the federal Constitution gives Congress implied power to protect it from interference by private acts, ${ }^{23}$ but does not give Congress implied power to exercise any control over a state's officers and agencies. ${ }^{24}$ It was also settled constitutional doctrine that a guarantee contained in the federal Constitution is not binding on the states unless explicitly made so. ${ }^{25}$ Many of the framers also seem to have believed, though with less basis in reported judicial opinions, that the federal government, in return for the allegiance of its citizens, has some duty to protect them in the enjoyment of their fundamental rights, even within the states. ${ }^{26}$ When this background of greater congressional power over individuals than over the states is taken into account, one can better understand how the framers may have supposed that a constitutional provision recognizing certain persons as United States citizens, forbidding the states to abridge their rights as such or deny them equal protection, and empowering Congress to enforce this by ap-

19. 16 Stat. 140 (1870).

20. 17 Stat. 13 (1871).

21. 18 Stat. 335 (1875).

22. FLACK, op. cit. supra note 4, at 210-77.

23. Prigg v. Pennsylvania, 41 U.S. (16 Pet.) 539 (1842) ; Ableman v. Booth, 62 U.S. (21 How.) 506 (1859).

24. Kentucky v. Dennison, 65 U.S. (24 How.) 66, 107 (1861). This case, like the two cited in note 23 supra, grew out of an aspect of the fugitive slave problem. All three cases must therefore have been quite familiar to abolitionists.

25. Barron v. Mayor of Baltimore, 32 U.S. (7 Pet.) 242 (1833).

26. TENBRoECK, op. cit. supra note 4, at 71-93, 192-200. 
propriate legislation, would result in a congressional enforcement power which would extend not only to private acts but even to "state action."

Flack's summary of the debates on the enforcement legislation indicates that Congress supposed it could reach private acts on either of two theories. First there was the power of the national government to secure to United States citizens the full and unhindered enjoyment of any right inherent in national citizenship. ${ }^{27}$ Second was the equal protection clause, which was read as equivalent to a guarantee that persons shall enjoy equality of protection. Congress thought that with power given to Congress by section five it could supply such equal protection whenever a state failed to do so. ${ }^{28}$ The first of these theoretical bases the courts have, as an abstract proposition, never denied. ${ }^{29}$ Its practical effect, however, was defeated by the narrow concept of the rights appurtenant to national citizenship developed in the Slaughterhouse cases. $^{30}$ The problem to which this article is addressed is: what happened to the second of these propositions, the one on which members of Congress most frequently and consistently relied ? $^{31}$

During the debates on the $\mathrm{Ku}$ Klux Act of $1871,{ }^{32}$ three major views on this question emerged. At one extreme, according to Prof. Harris, were those who

embraced a construction of the amendment which sustained almost unlimited congressional power to protect constitutional rights against both official and private action, to the point of displacing state authority altogether without awaiting abridgments of constitutional rights.

At the other extreme were those who argued "that congressional power was limited to the elimination of unequal laws and the correction of official or state action alone. ..." The latter view, though it is the one now considered orthodox, was in 1871 "advanced by a minority consisting almost exclusively of Democrats,"33 the same faction which had originally opposed the fourteenth amendment on the ground, among others, that it would bring about such a vast expansion of congressional power as to wipe out the states. There was, however, a moderate view standing between these two extremes, to the effect that "Congress had the responsibility to protect constitutional rights in the event of failure of the states to do so, but only after the states had failed or refused to do their duty."34 This moderate view was best expressed by president-to-be James A. Garfield, then a Representative from Ohio:

But the chief complaint is not that the laws of the State are unequal, but that even where the laws are just and equal on their face, yet, by a

27. FLACK, op. cit. supra note 4, at 210-77.

28. Ibid. See also Frank \& Munro, supra note 4, at 162-66; TENBroEK, op. cit. supra note 4 , at 98 .

29. See, e.g., United States v. Cruikshank, 92 U.S. 542, 552-53 (1876).

30. 83 U.S. (16 Wall.) 36 (1873).

31. FLACK, op. cit. supra note 4, at 210-77.

32. 17 Stat. 13 (1871), 42 U.S.C. § 1983 (1958).

33. HARRIS, op. cit. supra note 4 , at 45 .

34. Ibid. 
systematic maladministration of them, or a neglect or refusal to enforce their provisions, a portion of the people are denied equal protection under them. Whenever such a state of facts is clearly made out, I believe the last clause of the first section [of the fourteenth amendment] empowers Congress to step in and provide for doing justice to those persons who are thus denied equal protection.

Now if the ... pending bill can be so amended that it . . shall employ no terms which assert the power of Congress to take jurisdiction of the subject until such denial be clearly made, and shall not in any way assume the original jurisdiction of the rights of private persons and of property within the states - with these conditions clearly expressed ... I shall give it my hearty support. ${ }^{35}$

According to the traditional interpretation, the Supreme Court, when the Reconstruction legislation came before it, adopted the extreme view which, in Congress, had been expressed by the fundamentally anti-fourteenth amendment minority. This article will attempt to show that it did not; that it adopted instead the middle view of the moderate Republicans for whom Representative Garfield spoke. The theory is a subtle and complex one which is far less limiting in its effect on congressional enforcement power than the "state action" theory. It may be summarized as follows :

1. The fourteenth amendment places the primary responsibility for enforcing equality of civil rights on the states, but lodges in Congress adequate power to insure that the state's failure to discharge this responsibility shall not result in leaving these rights unprotected.

2. Where a racial group is discriminated against through a cultural pattern in which private acts play a part, the constitutional wrong, under the fourteenth amendment, is not the act of the individual, but the failure of the state to take adequate steps to prevent it, or to afford redress.

3. Congress, however, is not limited to striking directly at the constitutional wrong. It may also offset it by providing the protection which the state has failed to provide. But this power exists only when the state fails to do its duty.

4. Congress may provide in advance for a possible violation. But, if it does so, such legislation must be made conditional on the state's failure to act.

5. Congressional legislation which impinges directly on the conduct of private individuals and which operates uniformly regardless of the role played by the state is unconstitutional. But this is not because "private acts" are beyond the limits of congressional power. Rather, it is because: (a) Congress may not presume that states will fail to discharge their constitutional duties; (b) Congress may not deprive the states, in advance of any default on their part, of the very function the amendment commands them to perform.

The theory, of course, has never been directly tested since no federal civil rights legislation, limited in this fashion, has ever been enacted. The investigation will therefore require a somewhat painstaking analysis of the ipsissima

35. Congresstonat Grobe, 42d Cong., 1st Sess. 153 (Appendix) (1871). 
verba of the decided cases to uncover relevant dicta and to disclose the constitutional theory underlying the decisions. It also requires an investigation of what went before, both on and off the Court, since the context of the opinions gives them a significance which a mere reading does not disclose.

\section{The Context of the 1883 Decisions}

\section{A. The Reese Approach to Statutory Construction}

The initial cases on legislation under the fourteenth amendment must be understood in the context of the rather unusual approach to the question of the constitutionality of an overly broad statute which the Supreme Court adopted for the first time ${ }^{36}$ in the Reese case, ${ }^{37}$ and which seems to have been uniformly applied in other decisions involving the validity of federal civil rights legislation until it was finally rejected in $1960 . .^{38}$ The Reese decision was handed down on March 27, 1876, the same day the Cruikshank case was decided. The question in Reese was the validity of an indictment charging that the defendant, a state election official, had refused, because of race or color, to accept and count the vote of a qualified Negro citizen. However, the indictment was brought under a statute which, as the Court construed it, was broad enough to punish any unlawful interference with the right of franchise, whether or not based on race or color, at any election.

The Court begins by reasoning that, though the fifteenth amendment does not directly confer the right of suffrage on anyone, nevertheless it has given United States citizens the right not to be discriminated against with respect to suffrage because of race, color, or previous condition of servitude, and it has given Congress the power to enforce that right. ${ }^{39}$ Since the election involved was a state election, it is only because of the fifteenth amendment that Congress may act, and that amendment gives the power of enforcement only if the right to suffrage has been denied because of race. The statute is unconstitutional, therefore, since it may extend to denials of suffrage on other than racial grounds.

But if the situation before the Court is within the fifteenth amendment, what occasion is there for the Court to inquire whether the statute might be construed to reach situations which are outside it? Chief Justice Waite replies that penal statutes must be so construed that the citizen may know whether or not he is violating the law. It might be possible to save the constitutionality of the statute, to disregard some of its language, but the court may not write into the statute words of limitation that are not there. ${ }^{40}$

36. Stern, Separability and Separability Clauses in the Supreme Court, 51 Harv. I. Rev. 76, 82 (1937).

37. United States v. Reese, 92 U.S. 214 (1876).

38. United States v. Raines, 362 U.S. 17 (1960).

39. United States v. Reese, 92 U.S. 214 (1876).

40. Id. at 221. For analogous holdings, see also Baldwin v. Franks, 120 U.S. 678 (1887); and James v. Bowman, 190 U.S. 127 (1903). 
The decisions on the Civil Rights Act of 1875 follow the Reese pattern. The original decision ${ }^{41}$ holding that statute unauthorized by either the thirteenth or fourteenth amendments disposed of a group of cases, one of which involved segregation of an interstate railroad passenger. Yet the Court, over the express protest of Justice Harlan, ${ }^{42}$ stated:

And whether Congress, in the exercise of its power to regulate commerce amongst the several States, might or might not pass a law regulating rights in public conveyances passing from one State to another, is also a question which is not now before us, as the sections in question are not conceived in any such view. ${ }^{43}$

In 1913, in Butts v. Merchants \& Miners Transp. Co.,44 a Negro woman who had been segregated on a steamer passage between Boston and Norfolk brought suit to recover the penalties provided by Sections One and Two of the Civil Rights Act of 1875.45 Her lawyer did not challenge the decision in the Civil Rights Cases, but he contended that it decided only that the act could not take effect within the territorial jurisdiction of the states. The Court held unanimously that the law was not separable, that it could not make a law for the territories, the District of Columbia, and the high seas out of one which Congress had intended to apply to the whole nation.

Since the Court seems never to have suggested that a federal civil rights statute could be treated as valid in one application and invalid in another, all the cases on this legislation must be read with a basic caveat constantly in view: the fact that the Court held a particular statute unconstitutional does not necessarily mean that a valid statute could not have been framed to reach the same conduct.

\section{B. The Early Judicial Reaction}

In view of the reliance placed by the Supreme Court in later times on the allegedly contemporary construction of the fourteenth amendment by judges personally familiar with the circumstances of its framing and adoption, ${ }^{46}$ it is interesting to note the chronology of the cases from which we have derived our modern ideas about the effect of the amendment on congressional power. The Supreme Court decisions on this point begin with Reese ${ }^{47}$ and Cruikshank $^{48}$ in 1876, and culminate with Harris ${ }^{49}$ and the Civil Rights Cases ${ }^{50}$ in 1883. In 1876 the structure of Reconstruction was already crumbling and its impending defeat was evident. In 1883 its defeat was a fact which the North

41. Civil Rights Cases, 109 U.S. 3 (1883).

42. Id. at 60-61 (dissenting opinion).

43. Id. at 19.

44. 230 U.S. 126 (1913).

45. 18 Stat. 336 (1875).

46. E.g., Adamson v. California, 332 U.S. 46, 64 (Frankfurter, J., concurring) (1947).

47. United States v. Reese, 92 U.S. 214 (1876).

48. United States v. Cruikshank, 92 U.S. 542 (1876).

49. United States v. Harris, 106 U.S. 629 (1883).

50. 109 U.S. 3 (1883). 
had accepted and acquiesced in for six years. On the other hand, the earliest judicial reaction to fourteenth amendment enforcement legislation which I have been able to find parallels very closely the congressional theory. This is the case of United States $v$. Hall, ${ }^{51}$ decided on circuit in 1871, when the tide of Reconstruction was still running high. The opinion is by Circuit Judge W. B. Woods, who was later to be elevated to the supreme bench, and who was still later to deliver the Supreme Court's opinion in the Harris case.

The Hall case was decided on a demurrer to an indictment and, consequently, the opinion tells us very little about the facts. The indictment, drafted under Section Six of the Enforcement Act of 1870,52 charged that the defendants had conspired to injure, oppress, etc. certain citizens of the United States to prevent their free exercise and enjoyment of the rights of freedom of speech and freedom of assembly. It was contended on demurrer that these were not rights "granted or secured ... by the Constitution or laws of the United States," and hence the indictment failed to charge a violation of the statute. The court overruled the demurrer.

Unlike most later tribunals, Judge Woods begins his analysis of the fourteenth amendment with the first sentence declaring native born persons (with exceptions not relevant here) to be American citizens. This clause, he remarks, has the effect of making national citizenship define state citizenship whereas formerly the reverse had been true. ${ }^{53}$ Judge Woods then quotes the privileges or immunities clause of the amendment and defines such privileges and immunities as all those which are "fundamental," including all those singled out in the Bill of Rights. These rights are now secured against the states by the fourteenth amendment. ${ }^{54}$ Ignoring the due process clause, Woods

51. 26 Fed. Cas. 79 (No. 15,282) (C.C.S.D. Ala. 1871).

52. 16 Stat. 141 (1870).

53. By the original constitution citizenship in the United States was a consequence of citizenship in a state. By this clause this order of things is reversed. Citizenship in the United States is defined; it is made independent of citizenship in a state, and citizenship in a state is a result of citizenship in the United States. So that a person born or naturalized in the United States, and subject to its jurisdiction, is, without reference to state constitutions or laws, entitled to all the privileges and immunities secured by the constitution of the United States to citizens thereof.

26 Fed. Cas. at 81.

54. What are the privileges or immunities of citizens of the United States here referred to? They are undoubtedly those which may be denominated fundamental; which belong of right to the citizens of all free states, and which have at all times been enjoyed by the citizens of the several states which compose this Union from the time of their becoming free, independent and sovereign. Among these we are safe in including those which in the constitution are expressly secured to the people, either as against the action of the federal or state governments. Included in these are the right of freedom of speech, and the right peaceably to assemble.

To recur now to the first ground of demurrer: are these rights secured to the people by the constitution of the United States? We find that congress is forbidden to impair them by the first amendment, and the states are forbidden to impair them by the fourteenth amendment. Can they not, then, be said to be completely secured? 
next quotes the equal protection clause and notes that Congress is given an express grant of enforcement power:

From these provisions it follows clearly, as it seems to us, that Congress has the power, by appropriate legislation, to protect the fundamental rights of citizens of the United States against unfriendly or insufficient state legislation, for the fourteenth amendment not only prohibits the making or enforcing of laws which shall abridge the privileges of the citizens, but prohibits the states from denying to all persons within its jurisdiction the equal protection of the laws. Denying includes inaction as well as action, and denying the equal protection of the laws includes the omission to protect, as well as the omission to pass laws for protection. The citizen of the United States is entitled to the enforcement of the laws for the protection of his fundamental rights, as well as the enactment of such laws. Therefore, to guard against the invasion of the citizen's fundamental rights, and to secure their adequate protection, as well against state legislation as state inaction, or incompetency, the amendment gives congress the power to enforce its provisions by appropriate legislation. And as it would be unseemly for congress to interfere directly with state enactments, and as it cannot compel the activity of state officials, the only appropriate legislation it can make is that which will operate directly on offenders and offenses, and protect the rights which the amendment secures. The extent to which congress shall exercise this power must depend on its discretion in view of the circumstances of each case. If the exercise of it in any case should seem to interfere with the domestic affairs of a state, it must be remembered that it is for the purpose of protecting federal rights, and these must be protected even though it interfere with state laws or the administration of state laws. ${ }^{55}$

Two years after Hall, Supreme Court Justice Strong, who was later to write the Court's opinions in a very important group of fourteenth amendment cases, ${ }^{5 B}$ handed down an opinion in circuit, United States $v$. Given, ${ }^{57}$ dealing with congressional enforcement power under the fifteenth amendment. Congress, in the 1870 act, ${ }^{58}$ had undertaken to make it an offense to refuse, on grounds of race, color, or previous condition of servitude, to permit any citizen to perform any act necessary to become qualified to vote. Upholding an indictment under this provision, Justice Strong argued that the "primary object"

They are expressly recognized and both congress and the states are forbidden to abridge them. Before the fourteenth amendment, congress could not impair them, but the states might. Since the fourteenth amendment, the bulwarks about these rights have been strengthened, and now the states are positively inhibited from impairing or abridging them, and so far as the provisions of the organic law can secure Ibid. them they are completely and absolutely secured.

55. Id. at $81-82$.

56. Tennessee v. Davis, 100 U.S. 257 (1880) ; Strauder v. West Virginia, 100 U.S. 303 (1880) ; Virginia v. Rives, 100 U.S. 313 (1880); Ex parte Virginia, 100 U.S. 339 (1880).

57. 25 Fed. Cas. 1324 (No. 15,210) (C.C.D. Del. 1873). The Court gave no statement of facts other than that the defendant was found guilty and moved in arrest of judgment on the grounds of the unconstitutionality of the act.

58. 16 Stat. 140 (1870). 
of the Reconstruction amendments was to enlarge the rights of private persons. It does not necessarily follow that because the fifteenth amendment is worded as a prohibition upon the states and the federal government private persons did not gain rights because of it, or that Congress cannot enforce those rights. ${ }^{59}$ The fact that a mere recognition in the original Constitution of a master's right to reclaim a fugitive slave, ${ }^{80}$ even without any express provision for congressional enforcement, had been held to authorize Congress to enact a comprehensive statutory scheme to make the right fully effective, including legislation impinging directly on private individuals, ${ }^{81}$ led Justice Strong to conclude:

[T] he rights secured, recognized, and guaranteed by the thirteenth, fourteenth, and fifteenth amendments [are] objects of legitimate protection by the law-making power of the federal government. Those amendments have left nothing to the comity of the states affecting the subjects of their provisions. They manifestly intended to secure the right guaranteed by them against infringement from any quarter. ... It was well known when it [the fifteenth amendment] was adopted that in many quarters it was regarded with great disfavor. It might well have been anticipated that it would meet with evasion and hindrances, not from state legislatures, for their affirmative action was rendered powerless by it, or not from a state's judiciary, for their judgments denying the rights were reviewable by federal courts, but by private persons and ministerial officers .... It was not intended to leave the right without full and adequate protection. Earlier prohibitions to the states were left without any express power of interference by congress; but these later, encountering as they did so much popular prejudice and working changes so radical, were fortified by grants to congress of power to carry them into full effect - that is, to enact any laws appropriate to give reality to the rights declared. ${ }^{62}$

Thus, "It is . . a an exploded heresy that the national government cannot reach all individuals in the states." ${ }^{\circ 3}$ Seven years after the fourteenth amendment was proposed, five years after its ratification, the notion that congres-

59. The thirteenth, fourteenth, and fifteenth amendments of the constitution have confessedly extended civil and political rights, and, I think, they have enlarged the powers of congress. The primary object of the thirteenth, and of the first sections of the fourteenth and fifteenth was to secure to persons certain rights which they had not previously possessed. . . . It is true the [15th] amendment is in form a prohibition upon the United States, and upon the states, but it is not the less on that account an assertion of a constitutional right belonging to citizens as such. Surely it cannot be maintained that it conferred no rights upon persons. There are very many instances to be found in the constitution as it was before the recent amendments, in which rights of persons have been recognized and secured without any express grant.

25 Fed. Cas. at 1325.

60. U.S. Const. art. IV, § 2, cl. 3.

61. Prigg v. Pennsylvania, 41 U.S. (16 Pet.) 345 (1842); Ableman v. Booth, 62

U.S. (21 How.) 506 (1859).

62. 25 Fed. Cas. at 1326-27.

63. Id. at 1328. 
sional enforcement power under the fourteenth and fifteenth amendments cannot reach "private acts" was so far from Justice Strong's mind that, even in dealing with the case of a state official charged with making racially discriminatory use of his official powers, the Justice did not even bother to stress the "state action" aspects of the case before him.

\section{The Bradley Theory: Cruikshank in Circuit}

The first Supreme Court case involving congressional legislation passed to enforce the fourteenth amendment was United States $v$. Cruikshank. ${ }^{64}$ The case grew out of a bloody incident known as the "Colfax massacre." Louisiana two groups, one Democrat and one Republican, claimed to have won the 1872 election, and the federal government recognized the Republican faction. In the little town of Colfax, the Republican sheriff summoned a Negro posse and took over the building which was used as a court house. On April 13, 1873, a white mob surrounded the improvised court house, set it afire, and shot the Negroes to death as they emerged from the burning building. An investigation by the Department of Justice resulted in indictments under the Enforcement Act, ${ }^{66}$ charging that the defendants had "banded together" and "conspired" to injure, oppress, etc. their victims, citizens of the United States of African descent, in order to deprive them of: freedom of assembly, the right to bear arms, their lives and liberty without due process, the full benefit of all laws and proceedings, etc. enjoyed by white citizens, their rights, privileges and immunities, as citizens of the United States and of Louisiana, on account of race or color, the right to vote in future elections, and all rights and privileges secured to them in common with other citizens. The defendants were also charged with conspiring to injure their victims because they had voted in the election of 1872 , and with murdering them in executing the conspiracies charged.

The defense persuaded Justice Bradley of the Supreme Court, who was believed to doubt the constitutionality of the Enforcement Act, to sit with Judge W. B. Woods at the trial in Circuit Court. ${ }^{67}$ The defendants were acquitted on the murder counts, but convicted of the conspiracy charges. On motion in arrest of judgment, the judges were disagreed. Justice Bradley delivered an opinion ${ }^{68}$ holding the entire indictment void and the case was certified to the Supreme Court.

Parts of Justice Bradley's opinion have been quoted with approval by the Supreme Court, ${ }^{89}$ and none of it seems ever to have been expressly disavowed. Apart from its value as a precedent, however, it is a clue both to the early stages of the Supreme Court's thinking about the enforcement legislation and

64. 92 U.S. 542 (1876).

65. Cummings \& McFarland, Federal Justice 241-42 (1937).

66. 16 Stat. $140(1870)$.

67. CuMnings \& MCFARLAND, op. cit. supra note 65, at 243.

68. United States v. Cruikshank, 1 Woods 308, 25 Fed. Cas. 707 (No. 14,897) (1874).

69. E.g., United States v. Harris, 106 U.S. 629, 638 (1883). 
to the interpretation of the language used by Justice Bradley nine years later in his opinion for the Court in the Civil Rights Cases. ${ }^{70}$

"The main ground of objection," Justice Bradley begins,

is that the act is municipal in its character, operating directly on the conduct of individuals, and taking the place of ordinary state legislation; and that there is no constitutional authority for such an act, inasmuch as the state laws furnish adequate remedy for the alleged wrongs committed. ${ }^{71}$

So it is to be noted that the defendants themselves, as reported by Justice Bradley, did not contend that congressional enforcement power can never operate "directly on the conduct of individuals." They contended merely that, where "state laws furnish adequate remedy," Congress is not authorized to pass legislation so operating which is "municipal in its character" and takes "the place of ordinary state legislation."

In adopting this argument Justice Bradley does not intend to reach the conclusion that no implied powers over individuals are given to Congress by the fourteenth amendment since the words of the amendment are directed only at states. Rather, using a quotation from Prigg $v$. Pennsylvania, ${ }^{72}$ he denounces such narrow constitutional construction and contends that recognition of a right in the federal Constitution necessarily implies congressional power to do anything necessary to make it fully effective. Justice Bradley then observes that the constitutionally appropriate method of enforcement will depend on the character of the right, and a method applicable to one may not be applicable to another. As to those rights which form a part of the citizen's "political inheritance, ... . vindicated by centuries of stubborn resistance to arbitrary power,"

they belong to him as his birthright, and it is the duty of the particular state of which he is a citizen to protect and enforce them, and to do naught to deprive him of their full enjoyment. When any of these rights and privileges are secured in the constitution of the United States only by a declaration that the state or the United States shall not violate or abridge them, it is at once understood that they are not created or conferred by the constitution, but that the constitution only guaranties that they shall not be impaired by the state, or the United States, as the case may be. The fulfillment of this guaranty by the United States is the only duty with which that government is charged. The affirmative enforcement of the rights and privileges themselves, unless something more is expressed, does not devolve upon it, but belongs to the state government as a part of its residuary sovereignty. ... The enforcement of the guaranty does not require or authorize congress to perform the duty which the guaranty itself supposes it to be the duty of the state to perform, and which it requires the state to perform. The duty and power of enforcement take their inception from the moment that the state fails to comply with the duty enjoined, or violates the prohibition imposed. ${ }^{73}$

70. 109 U.S. 3 (1883).

71. 25 Fed. Cas. at 708-09.

72. Id. at 709-10; Prigg v. Pennsylvania, 41 U.S. (16 Pet.) 539 (1842).

73. Id. at 710 (emphasis added). 
The fourteenth amendment is not here conceived as consisting exclusively of restraints upon the states. It is conceived as also requiring the states to perform positive duties. Congressional enforcement power may take its inception from failure to perform the duty, as well as from violation of the prohibition. And when it does, there is not a word to suggest that Congress has only the obviously impractical power to command the state to act.

Applying these observations to the three Reconstruction amendments, Justice Bradley first discusses the thirteenth. ${ }^{74} \mathrm{He}$ views it as not merely a negative prohibition of slavery, but a positive bestowal of liberty on the former slaves, to which Congress has the power to give full effect. Since disability to be a citizen and to enjoy equal rights was deemed one form or badge of servitude, Congress had power to place the other races on the same plane of privilege as that occupied by the white race. This being the case, it necessarily had also the power

to go further and to enforce its declaration by passing laws for the prosecution and punishment of those who should deprive, or attempt to deprive, any person of the rights thus conferred upon him. Without having this power, congress could not enforce the amendment. ${ }^{75}$

This, however, is not a power to punish ordinary, non-racially motivated crimes against the Negro where the state has not been guilty of any failure to protect him.

All ordinary murders, robberies, assaults, thefts, and offenses whatsoever are cognizable only in the state courts, unless, indeed, the state should deny to the class of persons referred to the equal protection of the laws. Then, of course, congress could provide remedies for their security and protection. ${ }^{76}$

The fifteenth amendment, according to Justice Bradley, though negative in form, confers a positive right. That right, however, is not a right to vote, but merely a right not to be excluded from voting for the prohibited reasons. ${ }^{77}$ As to how this new right is to be enforced:

When the right of citizens of the United States to vote is denied or abridged by a state on account of their race, color, or previous condition of servitude, either by withholding the right itself or the remedies which are given to other citizens to enforce it, then, undoubtedly, congress has the power to pass laws to directly enforce the right and punish individuals for its violation, because that would be the only appropriate and efficient mode of enforcing the amendment. Congress cannot, with any propriety, or to any good purpose, pass laws forbidding the state legislature to deny or abridge the right, nor declaring void any state legislation adopted for that end. The prohibition is already in the constitutional amendment, and laws in violation of it are absolutely void by virtue of that prohibition. So far as relates to rendering null and void the obnoxious law, it is done already; but that does not help the person entitled to vote. By the supposition the state law gives him no remedy and no redress. It is clear,

74. Id. at 711-12.

75. Id. at 711 .

76. Id. at 711-12.

77. Id. at 712 . 
therefore, that the only practical way congress can enforce the amendment is by itself giving a remedy and giving redress. ${ }^{78}$

Where the state laws are in harmony with the amendment, or at least contain nothing repugnant thereto, Justice Bradley sees no impropriety in having Congress pass laws to enforce the right concurrently with the state. The citizen owes a dual allegiance to state and nation, and the same act may offend the laws of both.

The real difficulty in the present case is to determine whether the amendment has given to congress any power to legislate except to furnish redress in cases where the states violate the amendment. Considering, as before intimated, that the amendment, notwithstanding its negative form, substantially guaranties the equal right to vote to citizens of every race and color, I am inclined to the opinion that Congress has the power to secure that right not only as against the unfriendly operation of state laws, but against outrage, violence, and combinations on the part of individuals, irrespective of state laws. Such was the opinion of congress itself in passing the law at a time when many of its members were the same who had consulted upon the original form of the amendment in proposing it to the states. And as such a construction of the amendment is admissible, and the question is one at least of grave doubt, it would be assuming a great deal for this court to decide the law, to the extent indicated, unconstitutional. ${ }^{79}$

The limitations of the amendment, Justice Bradley hastens to add, must be kept in mind. Private interference with the right to vote is not within congressional power merely because the victims are Negroes, but only where such interference is racially motivated.

Summing up his views on the effect of the thirteenth and fifteenth amendments, Justice Bradley states:

The war of race, whether it assumes the dimensions of civil strife or domestic violence, whether carried on in a guerilla or predatory form, or by private combinations, or even by private outrage or intimidation, is subject to the jurisdiction of the government of the United States; and when any atrocity is committed which may be assigned to this cause it may be punished by the laws and in the courts of the United States; but any outrages, atrocities, or conspiracies, whether against the colored race or the white race, which do not flow from this cause, but spring from the ordinary felonious or criminal intent which prompts to such unlawful acts, are not within the jurisdiction of the United States, but within the sole jurisdiction of the states, unless, indeed, the state, by its laws, denies to any particular race equality of rights, in which case the government of the United States may furnish remedy and redress to the fullest extent and in the most direct manner. Unless this distinction be made we are driven to one of two extremes - either that congress can never interfere where the state laws are unobjectionable; however remiss the state authorities may be in executing them, and, however much a proscribed race may be oppressed; or that congress may pass an entire body of municipal law for the protection of person and property within the states, to operate concurrently with the state laws, for the protection and benefit of a par-

78. Id. at 713 (emphasis added).

79. Ibid. 
ticular class of the community. This fundamental principle, I think, applies to both the 13 th and 15 th amendments. ${ }^{80}$

Justice Bradley concludes with a few observations on the effect of the fourteenth amendment, in which he deals only with the privileges or immunities clause. He rejects the argument that this clause empowers Congress "to pass laws for directly enforcing all privileges and immunities of citizens of the United States. ..."By the rationale of the recent Slanghterhouse decision he should have answered this argument by saying that the rights of which the defendants' victims were deprived were conferred on them by the state of Louisiana and were quite unconnected with their United States citizenship. But Justice Bradley, evidently still clinging to his Slaughterhouse dissent, answers the argument in a quite different way:

If the power to enforce the amendment were equivalent to the power to legislate generally on the subject matter of the privileges and immunities referred to, this would be a legitimate conclusion. But, as before intimated, that subject matter may consist of rights and privileges not derived from the grants of the constitution, but from those inherited privileges which belong to every citizen, as his birthright, or from that body of natural rights which are recognized and regarded as sacred in all free governments; and the only manner in which the constitution recognizes them may be in a prohibition against the government of the United States, or the state governments, interfering with them. It is obvious, therefore, that the manner of enforcing the provisions of this amendment will depend upon the character of the privilege or immunity in question. If simply prohibitory of governmental action there will be nothing to enforce until such action is undertaken. How can a prohibition, in the nature of things, be enforced until it is violated? Laws may be passed in advance to meet the contingency of a violation, but they can have no application until it occurs. ${ }^{81}$

This prelude does not lead Justice Bradley to the conclusion that congressional enforcement, even under the privileges and immunities clause, can never reach "private acts." Instead :

If these views are correct, there can be no constitutional legislation of congress for directly enforcing the privileges and immunities of citizens of the United States by original proceedings in the courts of the United States, where the only constitutional guaranty of such privileges and immunities is, that no state shall pass any law to abridge them, and where the state has passed no laws adverse to them, but, on the contrary, has passed laws to sustain and enforce them. ${ }^{82}$

Justice Bradley, then, believed that racially motivated private acts, designed to deprive Negroes of equality of rights, might be reached by Congress under the thirteenth amendment, regardless of the role played by the state. They can also be reached under the fifteenth, where racial equality in suffrage is the right attacked. Private conduct which is not racially motivated is not within congressional power merely because the victims are Negroes. But legislation

\footnotetext{
80. Id. at 714 (emphasis added).

81. Ibid.

82. Ibid.
} 
is within congressional power when the state "denies to any particular race equality of rights," either because state laws are objectionable or because "state authorities" are "remiss . . . in executing" state laws. Whether this power to provide congressional protection against private acts when state protection fails is attributed to the thirteenth amendment, to the equal protection clause of the fourteenth, or both is not entirely clear. The matter is adverted to as part of the thirteenth amendment discussion, but the language of equal protection is used. There is no separate discussion of the equal protection clause. It is clear that, when state protection fails, Congress is not limited to exhorting the state to act, and to punishing lax officials. Instead, "the government of the United States may furnish remedy and redress to the fullest extent and in the most direct manner."

If the power to extend national protection where state protection fails is attributed solely to the thirteenth amendment, then there is no explicit statement as to the full extent of congressional power to reach "private acts" under the fourteenth amendment. It is said, however, that under the fourteenth amendment Congress has no power to move against private acts where the state has in no way failed in its duty. But the reason for this is not that congressional enforcement power can reach only acts which the amendment itself forbids, a rationale which would contradict Justice Bradley's own reading of the fifteenth amendment, as well as the Prigg v. Pennsylvania approach to construction, which he took as his starting point. The reason is that Congress would then be taking over the very duty which the amendment "requires the state to perform," without affording the state any opportunity to perform it.

It seems clear that the theory which Justice Bradley in the end adopts is the same as that which, in the beginning, he stated as the defendants' contention. But it is not a theory that "private acts," as such, are beyond the reach of congressional enforcement power. It is rather a theory that, where "the state laws furnish adequate remedy" Congress is not authorized to assume the initial and primary responsibility for regulating private acts by means of legislation which is "municipal in its character" and takes "the place of ordinary state legislation."

\section{Cruikshank in the Supreme Court}

In the Supreme Court, Justice Bradley's judgment quashing the indictment was affirmed in an opinion ${ }^{83}$ which was substantially unanimous, although Justice Clifford, concurring on procedural grounds, found it unnecessary to discuss any constitutional questions.

Chief Justice Waite, delivering the opinion of the Court, is not nearly so luminous as Bradley. He restates the Slaughterhouse distinction in sweeping generalities. Each citizen of the United States who resides in a state has two allegiances and two citizenships. His rights under one may not be the same as his rights under the other. Each of the two governments has a duty to protect him, but only within the limits of its powers.

83. United States v. Cruikshank, 92 U.S. 542 (1876). 
The right of free assembly is both too ancient and too fundamental to have anything to do with national citizenship.

The government of the United States, when established, found it in existence, with the obligation on the part of the states to afford it protection. As no direct power over it was granted to Congress, it remains . . . subject to state jurisdiction. ${ }^{84}$

It is very difficult to say what this means. The right of free assembly "remains subject to state jurisdiction." There is nothing necessarily inconsistent with Bradley about that. The state is not assigned merely a negative disability to invade the right, but an affirmative "obligation to afford it protection." But that obligation does not spring from the fourteenth amendment, or even from the Constitution; it was in the bosom of the natural law when the United States was established. But to whom is the obligation owed? Is it merely the state's obligations to its citizens, or has the fourteenth amendment made the affirmative protection of citizens in the enjoyment of their rights an obligation which the state owes to the United States? If the latter, is Congress' power limited to trying to coerce an unwilling state to take affirmative action - the complete impracticality of which is pointed out in the opinion which the Chief Justice is reviewing - or is there some point at which the failure of the state to discharge its obligations would give Congress power to assume the function? "No direct power" over the subject has been granted to Congress. But what is the nature of that indirect power in Congress, the possibility of which is not excluded?

Chief Justice Waite simply leaves these questions unanswered. But, significantly, he leaves Justice Bradley's theories unchallenged, in spite of the fact that he is reviewing and affirming the Circuit Court decision which will be cited for any proposition which the Supreme Court fails to disavow. If the majority of the Supreme Court were clearly of the opinion that Bradley's approach was unsound, it would seem that a few well-placed dicta in the majority opinion would be in order. Significantly, too, Justice Bradley silently concurs. If he understood the majority opinion to reject his views, though agreeing with his disposition of the case, there seems to be no reason why he should not repeat his views in a special concurrence. It is conceivable, of course, that Justice Bradley, even in this short interval, may have changed his views, but we have no indication that he did. ${ }^{85}$

Chief Justice Waite found that the right of free assembly was not, in general, a privilege of United States citizenship, but he qualified this view:

The right of the people peaceably to assemble for the purpose of petitioning Congress for a redress of grievances, or for anything else con-

84. Id. at 551 .

85. Also silently concurring was Justice Strong, who had already endorsed congressional power to deal with private acts, speaking in a fifteenth amendment case, but using language obviously addressed to the fourteenth amendment as well. See text accompanying notes 59-63 supra. Justice Strong was still to write opinions for the Court in an important group of fourteenth amendment cases, implying a very broad view of congressional enforcement power. See text accompanying notes 89-98 infra. 
nected with the powers or the duties of the National Government, is an attribute of National Citizenship and, as such, under the protection of and guaranteed by, the United States. . . . If it had been alleged in these counts that the object of the defendants was to prevent a meeting for such a purpose, the case would have been within the statute and within the scope of the sovereignty of the United States. ${ }^{88}$

Here, there is a slight suggestion that Chief Justice Waite may be seeking a different compromise from the one Justice Bradley suggested between the two extremes which he had pointed out. Instead of letting Congress act on individuals when the state has failed to discharge its constitutional obligations, let Congress act on individuals when the right at stake is one which the nation, as such, has an interest in preserving. But this distinction is not brought forward as an interpretation of the fourteenth amendment or any other specific clause of the Constitution. Rather:

The very idea of a government, republican in form, implies a right on the part of its citizens to meet peaceably for consultation in respect to public affairs and to petition for a redress of grievances. ${ }^{87}$

It almost seems that the Chief Justice prefers not to get his constitutional law too closely entangled with the text of the document. But it is clear that, if he does intend to substitute this new distinction for the one suggested by Justice Bradley, he does not do so in the name of the new amendments. So the essential question - what are Congress' new powers, and upon whom may they be exercised - remains unanswered.

The Chief Justice also expressly takes the position that whatever may be the rights which belong to a United States citizen as such, those rights Congress may protect against individual acts of aggression. He finds that the counts on right to assemble and right to bear arms fail, because these rights are not guaranteed against individual invasion, and the count on the deprivation of life and liberty also fails, because the due process clause "adds nothing to the rights of one citizen as against another." But to reach a similar conclusion regarding the count for depriving the victims of "the full benefit of all laws and proceedings," he finds it necessary to observe that there is "no allegation that this was done because of the race or color of the persons conspired against." He also points out that because this allegation was omitted, no question arises under the Civil Rights Act of 1866 . So it seems that, though the equal protection clause also does not "add anything to the rights which one citizen has under the Constitution against another," it is impliedly admitted that Congress might be able to add something to the rights of one individual against another, at least when a race motive is involved.

The implications of Waite's opinion, then, are that private conduct not racially motivated does not constitute a violation of the due process clause or the equal protection clause. Therefore, when a federal statute makes it a crime for individuals to conspire to deprive citizens of their constitutional

86. 92 U.S. at 552-53.

87. Id. at 552 . 
rights, an allegation that defendants conspired to deprive citizens of their lives and liberty without due process, or to deny them equal protection, is not sufficient to charge a violation of this statute. Further, the privileges or immunities of national citizenship may be protected against private aggression. But these rights do not include a general right of freedom of assembly, though they do include the right to assemble to discuss national issues. There is nothing here inconsistent with Bradley, except the view that the privileges or immunities clause does not protect fundamental rights. This difference does not touch Bradley's theory, since he, forewarned by Slaughterhouse, worked out his whole approach without relying on that clause.

\section{E. The 1880 Cases}

On the whole, the judicial history of the Reconstruction civil rights legislation is one of the progressive dismantling by the courts of most of what Congress had attempted. But there was one sharp interruption of this process in 1880 with a group of five decisions, ${ }^{88}$ predominantly nationalistic in tone, two of them dealing directly with the powers of Congress under the fourteenth amendment. In each, Justices Clifford and Field in dissent maintained that the police jurisdiction of the states is a sacred area in which Congress, even in the exercise of an express power, may not meddle. In each, the majority refused to consider the tenth amendment, or the nature of the federal system, as implying any limitations on the exercise of an express federal power.

In Ex parte Virginia ${ }^{89}$ the Court upheld, in the first such holding, and the only one prior to $1945,{ }^{90}$ a federal criminal statute passed under the authority of the fourteenth amendment. The measure involved was section four of the Civil Rights Act of $1875,{ }^{91}$ which made it a crime to exclude any citizen, on grounds of race or color, from a state or federal jury. The Supreme Court upheld an indictment charging a state judge with having excluded Negroes in the selection of a state jury. It pronounced the act "fully authorized by the Constitution." Justice Field, dissenting, argued with respect to all three of the Reconstruction amendments that:

The provision authorizing Congress to enforce them by appropriate legislation does not enlarge their scope, nor confer any authority which would not have existed independently of it. No legislation would be appropriate which should contravene the express prohibitions upon Congress .... [T] he implied prohibitions .... are as obligatory as the express prohibitions. The Constitution .... contemplates the existence and independence of the States in all their reserved powers. . . Legislation could not, therefore, be appropriate which, under pretence of prohibiting a State from doing certain things, should tend to destroy it, or any of its

88. Tennessee v. Davis, 100 U.S. 257 (1879); Strauder v. West Virginia, 100 U.S. 303 (1879) ; Virginia v. Rives, 100 U.S. 313 (1879) ; Ex parte Virginia, 100 U.S. 339 (1879) ; Ex parte Siebold, 100 U.S. 371 (1879).

89. 100 U.S. 339.

90. Screws v. United States, 325 U.S. 91 (1945).

91. 18 Stat. 335 (1875). 
essential attributes. To every State, as understood in the American sense, there must be, with reference to the subjects over which it has jurisdiction, absolute freedom from all external interference in the exercise of its legislative, judicial, and executive authority. ${ }^{92}$

From the presence of the due process clause in the fourteenth amendment, Justice Field argues that congressional enforcement was never intended. He maintains that congressional power to enforce such a clause would result in authority to prescribe the conditions on which property can be acquired and held, the means by which the liberty of the citizen should be protected, and a code of criminal procedure for the states. Hence:

The existence of this clause in the Amendment is to me a persuasive argument that those who framed it, and the Legislatures of the States which adopted it never contemplated that the prohibition was to be enforced in any other way than through the judicial tribunals, as previous prohibitions upon the States had always been enforced. ${ }^{93}$

Justice Strong, speaking for the majority, replied to Justice Field's latter argument by calling attention to the congressional enforcement clause which appears at the end of each of the Reconstruction amendments :

All of the Amendments derive much of their force from this latter provision. It is not said that the judicial power of the general government shall extend to enforcing the prohibitions and to protecting the rights and immunities guaranteed. ... It is the power of Congress which has been enlarged .... Whatever legislation is appropriate, that is, adapted to carry out the objects the Amendments have in view, whatever tends to enforce submission to the prohibitions they contain, and to secure to all persons the enjoyment of perfect equality of civil rights and the equal protection of the laws against state denial or invasion, if not prohibited, is brought within the domain of congressional power. ${ }^{94}$

To Justice Field's argument from the independence of a state, "as understood in the American sense," Strong responded :

Nor does it make any difference that such legislation is restrictive of what the State might have done before the constitutional amendment was adopted. ... [A] state cannot ... deny to the general government the right to exercise all its granted powers, though they may interfere with the full exercise and enjoyment of rights she would have had if those powers had not been thus granted. Indeed, every addition of power to the general government involves a corresponding diminution of the governmental powers of the States. It is carved out of them ....

Such legislation must act upon persons, not upon the abstract thing denominated a State, but upon the persons who are the agents of the State in the denial of the rights which were intended to be secured.95

The last remark must be read in the context of the particular case. The issue between Field and the majority is whether Congress, to enforce the amend-

92. 100 U.S. 339, 361-62.

93. Id. at 366 .

94. Id. at $345-46$ (emphasis added).

95. Id. at 346-47. 
ment, can go so far as to control one of the state's own instrumentalities. "Persons who are the agents of the State" are contrasted not with private individuals but with "the abstract thing denominated a State."

The case does not involve and the opinions do not consider whether circumstances can ever arise in which congressional enforcement power may impinge directly on the conduct of private individuals toward each other. But the statements that it is congressional power, not judicial power, which has been enlarged, and that Congress, in the absence of a prohibition, can do anything adapted to carry out the objects of the amendments "and to secure to all persons the enjoyment of perfect equality of civil rights," suggest a very broad doctrine indeed. The latter phrase may or may not be read as limited by the expression "against state denial or invasion." But, if it is, state "denial," which is contrasted to "invasion," would seem to refer to a failure to afford affirmative protection.

In the scope of congressional power which its language would seem to imply, Justice Strong's opinion in Strauder $v$. West Virginia ${ }^{96}$ is even broader. There a Negro had been indicted in the state court for murder. A state statute, enacted after the Reconstruction amendments, limited jury service to whites. Under these circumstances, the Court held that Section 641 of the Revised Statutes, providing for the removal of proceedings by defendants unable to enforce in a local tribunal rights granted them by the Civil Rights Bill, authorized the removal to federal court of the trial of this purely state offense. The Court held also that the statute, as thus construed, was a very appropriate one for the enforcement of the fourteenth amendment. Justice Strong for the Court argued that the common purpose of the thirteenth, fourteenth, and fifteenth amendments is to secure all civil rights to the Negro and that they must be interpreted in the light of that purpose. The fourteenth makes no attempt to enumerate the rights it protects, but uses language designedly general to make its coverage as comprehensive as possible. And, although its language is prohibitory, every prohibition implies rights and immunities, prominent among which is immunity from inequality of legal protection, either for life, liberty, or property. Here, again, the question of congressional legislation impinging on private idividuals is not before the Court and is not discussed. But the theoretical approach is that the amendment creates affirmative rights in individuals, not merely restraints upon the states. And the Court expressly takes the view, of the utmost importance for this question, that the form and manner of the protection to be provided are questions of legislative discretion for Congress.

The juxtaposition of this case with Virginia $v$. Rives ${ }^{97}$ provides an interesting clue to the direction of the Court's thinking at this point. As in the Strauder case, the defendant was charged with murder and sought to remove his case to the federal court. His petition for removal alleged that, although Negroes were eligible for jury service by state law, no Negroes had ever been

96. 100 U.S. 303 (1879).

97. 100 U.S. 313 (1879). 
chosen for jury services in the state; that all members of the venire were white; that he had moved to have a venire composed one-third of Negroes selected, and this motion had been refused; that he was charged with the murder of a white man, and that feeling in the community was so high that a trial by an all-white jury could not be fair and impartial. The Court decided that all of this did not add up to a case for removal under the statute. It limited the statute to cases in which the defendant could not secure his rights because the state law itself was unfavorable. The statute left other cases of denials of equal rights by state courts to the revisory power of the Supreme Court.

This is expressly a construction of the removal statute, not of the Constitution. The Court points out that the reach of the statute is not as broad as that of the amendment and finds it unnecessary to consider whether a removal statute broad enough to remove a case merely because of a state court's discriminatory application of the law would be constitutional.

The aspect of the case which relates it to Strauder is this statement:

But when a subordinate officer of the State, in violation of State law, undertakes to deprive an accused party of a right which state law accords him ... it ought to be presumed the court will redress the wrong.98

The idea that it must be presumed that the state will discharge its obligations reappears frequently in the cases. Thus, in Neal $v$. Delaware ${ }^{99}$ the state statute, enacted in 1848, confined jury service to electors, and the state constitution, adopted in 1831, confined the suffrage to whites. But it was held that this did not make a case within the rule that there is a right of removal where the discrimination is on the face of the law. The state constitution must be understood as having been automatically amended by the effect of the fifteenth amendment in striking the word "white" from its suffrage sections. The Court remarked:

The presumption should be indulged, in the first instance, that the State recognizes, as is its plain duty, an amendment of the Federal Constitution, from the time of its adoption, as binding on all its citizens and every department of its government, and to be enforced, within its limits, without reference to any inconsistent provisions in its own Constitution or statutes. ${ }^{100}$

By the presumption in Neal and Rives, it is clear that removal in the Strauder case was available only because the state statute had been passed after the amendment. Thus the advance presumption that a state will always obey the federal Constitution had been rebutted in what is perhaps the only way such a presumption could be rebutted: the state had officially announced its advance intentions in incontrovertible form.

In Ex parte Siebold, ${ }^{101}$ which was decided contemporaneously with the Virginia, Rives, and Strauder cases, the fourteenth amendment was not in-

98. Id. at 321-22.

99. 103 U.S. 370 (1881).

100. Id. at 389-90.

101. 100 U.S. 371 (1879). 
volved, but the case shows the same general pattern of thinking, with Clifford and Field in dissent and the majority refusing to divide state and federal functions into watertight compartments. Congress had passed a statute imposing federal criminal penalties on state election officials for failure to discharge, at a federal election, duties imposed upon them by state law. The majority in an opinion by Justice Bradley held this valid under the constitutional power of Congress to "make or alter" the regulations in federal elections :

The objection that the laws and regulations, the violation of which is made punishable by the acts of Congress, are State laws and have not been adopted by Congress, is no sufficient answer to the power of Congress to impose punishment .... The State laws which Congress sees no occasion to alter, but which it allows to stand, are in effect adopted by Congress. It simply demands their fulfillment. Content to leave the laws as they are, it is not content with the means provided for their enforcement. It provides additional means for that purpose; and we think it is entirely within its constitutional power to do so. ... [T] he duties devolved on the officers of election are duties they owe to the United States as well as to the State .... 102

It would, perhaps, be pressing this argument too far to suggest that where the stat law on its face gives adequate protection to civil rights, Congress might adopt it and add further means for its enforcement. The fourteenth amendment does not contain the "make or alter" language which is under consideration here. But at least it establishes that the nature and structure of the federal system do not preclude the possibility that enforcement of state laws by state officers may become a federal function.

\section{Tee Harris and Civil Rights Cases}

Two cases decided in 1883, United States $v$. Harris ${ }^{103}$ and the Civil Rights Cases, ${ }^{104}$ are customarily cited as having established the doctrine, already said to have been announced in Cruikshank, that the power conferred on Congress by the fourteenth amendment can never extend to private acts, but only to the states and the agents by which states act. The precedents for Harris and the Civil Rights cases, however, do not approach stating this doctrine. The nearest thing to an authority for it is the Cruikshank case. ${ }^{105}$ But the Cruikshank case decides nothing on Congress' fourteenth amendment enforcement power. It decides merely that the fourteenth amendment does not, of its own force, without congressional action, impose constitutional obligations on private individuals. Hence, when Congress provides in general terms that it shall be a crime to conspire to deprive a citizen of his rights under the federal Constitution and laws, a mere private wrong not sanctioned in any way by the state, is not within that statute. It does not say, nor does it clearly imply that

102. Id. at 388-89.

103. 106 U.S. 629 (1883).

104. 109 U.S. 3 (1883).

105. 92 U.S. $542(1876)$. 
Congress has no power to impose new duties on private individuals. It contains a rather strong implication that Congress does have such a power, at least where private wrongs are racially motivated.

United States $v$. Harris ${ }^{106}$ was an indictment of Harris and nineteen others for lynching four persons, who were in the custody of a deputy sheriff. The indictment was framed under Section 5519 of the Revised Statutes, which had been part of section two of the $\mathrm{Ku}$ Klux Act of $1871 . .^{107}$ The section made it a crime to conspire to deprive any person of equal protection or to prevent or hinder the authorities of any state or territory from giving equal protection. The Court held the statute unconstitutional, Justice Harlan dissenting without opinion. The Court's opinion is by Justice Woods, who, as circuit judge twelve years before, had expounded the congressional theory of the fourteenth amendment in United States v. Hall. ${ }^{108}$

After citing Slanghterhouse to establish the constitutional irrelevance of the fact that the deceased were citizens of the United States, Justice Woods relies on three authorities: Justice Bradley's opinion in circuit in Cruikshank, Chief Justice Waite's opinion in the same case, and Viriginia v. Rives. But, as we have seen, the Bradley opinion is expressly in favor of a congressional power to reach private action, but only where the act is racially motivated and where the state's protection has been withheld. Waite's opinion says only that an outrage by private persons, not affirmatively alleged to be motivated by racial antagonism, cannot, independently and of its own force, amount to a violation of the fourteenth amendment. Most interesting of all, Virginia $v$. Rives does not touch the private action problem. It deals with action which was admittedly that of the state - with the presumption that a state will not fail to redress a wrong which is a violation of its own laws.

Referring to these cases, Justice Woods declares:

These authorities show conclusively that the legislation under consideration finds no warrant for its enactment in the Fourteenth Amendment.

The language of the amendment does not leave the subject in doubt. When the State has been guilty of no violation of its provisions, ... when, on the contrary, the laws of the State, as enacted by its legislative, and construed by its judicial, and administered by its executive departments, recognize and protect the rights of all persons, the amendment imposes no duty and confers no power upon Congress. ${ }^{109}$

Observe the expansive conditions which must be met before the statement "the Amendment . . . confers no power upon Congress" takes effect. Legislatively, judicially, and administratively, the state must not merely recognize but protect the rights of all persons.

Section 5519 of the Revised Statutes is not limited to take effect only in case the State shall abridge the privileges or immunities of citizens of

106. 106 U.S. 629 (1883).

107. 17 Stat. 13 (1871).

108. See text accompanying notes 53-55 supra.

109. 106 U.S. at 639 (emphasis added). 
the United States, or deprive any person of life, liberty, or property without due process of law, nor deny to any person the equal protection of the laws. It applies, no matter how well the State may have performed its duty. 110

If the rule were that the power of Congress under the amendment cannot reach private acts, all this discussion would be quite meaningless and unnecessary. It would be sufficient to point out that the statute on which the indictment was based was one penalizing purely private acts, and that would dispose of the whole case. There is a clear negative inference here that Congress' power can reach private individuals, but only when the state has somehow failed in its duty.

As, therefore, the section of the law under consideration is directed exclusively against the action of private persons, without reference to the laws of the State or their administration by her officers, we are clear in the opinion that it is not warranted by any clause in the Fourteenth Amendment. ${ }^{111}$

This is the same criticism which Representative Garfield had made of the statute when it was before the Congress. ${ }^{112}$ And in holding the statute unconstitutional, Justice Woods, who wrote the Hall opinion and who voted to uphold the Cruikshank indictment, is not adopting the extreme view that congressional enforcement power never extends to "private acts." $\mathrm{He}$ is adopting the view of Garfield and the moderates that it does not extend to such acts in the absence of some showing that state protection has failed or has been withheld. And he is applying the latter view in the light of the presumptions, established in Virginia v. Rives and Neal v. Delaware, that the state will perform its constitutional duties and will enforce its own laws.

Did the Court, after expressing the moderate view in Harris, shift to the extreme states-rights view a few months later in the Civil Rights Cases? ${ }^{113}$ In the latter case, the Court held unconstitutional those sections of the Civil Rights Act of $1875^{114}$ which had attempted to prohibit racial discrimination in the enjoyment of the facilities of inns, public conveyances, and places of public amusement. Justice Bradley stated that:

The first section of the Fourteenth Amendment (which is the one relied on), after declaring who shall be citizens of the United States, and of the several States, is prohibitory in its character, and prohibitory upon the States. . . . [T] he last section of the amendment invests Congress with power to enforce it by appropriate legislation. To enforce what? To enforce the prohibition. To adopt appropriate legislation for correcting the effects of such prohibited State laws and State acts, and thus to render them effectually null, void and innocuous. This is the legislative power conferred upon Congress, and this is the whole of it. It does not invest Congress with power to legislate upon subjects which are within the

110. Ibid.

111. Id. at 640 (emphasis added).

112. See text accompanying note 35 supra.

113. 109 U.S. 3 (1883).

114. 18 Stat. 335 (1875). 
domain of State legislation; but to provide modes of relief against State legislation, or State action, of the kind referred to. It does not authorize Congress to create a code of municipal law for the regulation of private rights; but to provide modes of redress against the operation of State laws, and the action of State officers executive or judicial, when these are subversive of the fundamental rights specified in the amendment. Positive rights and privileges are undoubtedly secured by the Fourteenth Amendment; but they are secured by way of prohibition against State laws and State proceedings affecting those rights and privileges, and by power given to Congress to legislate for the purpose of carrying such prohibition into effect: and such legislation must, necessarily, be predicated upon such supposed State laws or State proceedings, and be directed to the correction of their operation and effect. A quite full discussion of this aspect of the amendment may be found in United States v. Cruikshank ... Virginia $v$. Rives . . . and Ex parte Virginia . . . . 115

This language, taken by itself, is certainly open to the construction that congressional enforcement power cannot deal with private acts. Yet it does not clearly and unequivocally say this. It says merely that enforcement legislation must be "predicated upon some supposed state law or state proceedings, and be directed to the correction of their operation and effect." Though it may be a little awkward to think of a state failure to protect as constituting a "law" or "proceeding," the notion that congressional protection against private acts may be extended where state protection fails or is withheld is not explicitly excluded. Furthermore, here, as in Harris, the nature of the authorities cited throws light on what is intended by the language used. Cruikshank held merely that the amendment does not, of its own force, give one private individual rights against another (not that congressional enforcement legislation may not do so). Ex parte Virginia expresses a very broad view of congressional enforcement power and holds that it extends even to (but not necessarily only to) control of the state's own instrumentalities. Here, as in Harris, if one assumes that the Court is distinguishing between state and private action, then it is impossible to account for the invocation of Virginia $v$. Rives, which dealt with action admittedly that of the state. If the Court were now saying that under no circumstances can congressional enforcement power forbid something which is not "state action," then this would be new doctrine, going considerably beyond anything the Court had previously held. Surely in that case Justice Bradley would not have said that a "quite full discussion" of this new point was to be found in three cases which in fact do not discuss it at all.

Had Justice Bradley stopped here, this view of his opinion might be deemed tenuous and uncertain. However, he did not stop. Instead, as Justice Woods had done in Harris, he went on to develop an argument which, if congressional power were wholly limited to dealing with "state action," would have been entirely superfluous:

An inspection of the law shows that it makes no reference whatever to any supposed or apprehended violation of the Fourteenth Amendment

115. 109 U.S. at 10-12. 
on the part of the States. It is not predicated on any such view. It proceeds ex directo to declare that certain acts committed by individuals shall be deemed offences, and shall be prosecuted and punished by proceedings in the courts of the United States. It does not profess to be corrective of any constitutional zerong committed by the States; it does not make its operation to depend upon any such wrong committed. It applies equally to cases arising in States which have the justest laws respecting the personal rights of citizens, and whose authorities are ever ready to enforce such laws, as to those which arise in States which may have violated the prohibition of the amendment. In other words, it steps into the domain of local jurisprudence, and lays down rules for the conduct of individuals in society towards each other, and imposes sanctions for the enforcement of those rules, without referring in any manner to any supposed action of the State or its authorities. ${ }^{116}$

If the statute were void because prevention of private acts of discrimination is beyond congressional power, then the fact that the state has "the justest laws" to protect civil rights and that its authorities are ever ready to enforce such laws could not make it any the more void. It seems plain enough that this is Justice Bradley's old theory that congressional enforcement power takes its "inception from the moment that the state fails to comply with the duty enjoined" and that, absent such failure, Congress is not authorized "to perform the duty which the guaranty itself supposes it to be the duty of the state to perform, and which it requires the state to perform." Or rather, we are back to the version of that theory, as merged with presumptions that the state will perform its constitutional duties and enforce its own laws, which the Court had already adopted in the Harris case.

\section{ConcLUSIONS}

Whatever one may think of its application in the particular cases, the underlying theory of the early cases construing congressional power under the fourteenth amendment is not very far from what some recent pro-civil rights commentators have concluded the theory should be. ${ }^{117}$ Nor is it very far from some recent interpretations of the original understanding with which the fourteenth amendment was enacted. ${ }^{118}$ The theory that congressional power to

116. Id. at 14 (emphasis added).

117. See, e.g., Peters, Civil Rights and State Non-Action, 34 Notre Dame LAw. 303, 332-33 (1959). See also HARRIs, op. cit. stipra note 4, at 53, stating that Garfield's view "is the only interpretation that is compatible with the maintenance of federalism and simultaneously gives meaning to the equal protection clause and the fifth section...."

118. [D]espite differences of opinion concerning the scope of congressional power under the amendment, a majority of the members of the Thirty-ninth, Forty-second, and Forty-third Congresses, some of whom were members of all three and of the Committee of Fifteen on Reconstruction, believed that the equal protection clause did more than condemn official or state action. They believed that it vested Congress at the very least with a primary power to set aside unequal state laws and a secondary power to afford protection to all persons in their enjoyment of constitu- 
enforce the fourteenth amendment can deal only with "state action" will not stand up. It is obviously at odds with the original understanding. Even if we are not certain precisely what the original understanding was, we know that it could not have been this. The theory leaves still unsolved - and still incapable of any national solution - the principal problem which the amendment was designed to remedy. The cases which are believed to have established this theory do not do so.

It is difficult to say whether the more moderate and complex theory which the cases actually express (if I read them correctly) can still be exhumed after generations have grown accustomed to a contrary reading. It is still more difficult to say just how useful, if useful at all, that theory might prove to be if its rescue and revitalization are still possible. Admittedly, adoption of this theory would leave many difficult problems unresolved.

Some may doubt, too, whether decisions such as those in the Cruikshank, Harris, and Civil Rights Cases are now of anything more than historical interest. Those cases, whether read one way or the other, are expressions of a judicial attitude vastly different from that which now obtains. Surely the present Court, if compelled to choose between following those cases (as they have generally been understood) or overruling them, would choose the latter. Yet, unless we are willing to attribute to Congress vast and undefined powers which might alter the federal-state balance more than we wish or need to alter it, overruling those cases would not solve the problem, but merely restate it: if "state action" is not the limit of congressional power to enforce the fourteenth amendment, then what is that limit? Perhaps the Garfield-BradleyWoods theory might furnish an acceptable answer to that question.

Very little fourteenth amendment enforcement, either judicial or legislative, had received judicial approval by 1883 . The growth of the judicial decisions under the fourteenth did not fairly begin until after that date. Thereafter, the power of the courts under the fourteenth evolved greatly while the power of Congress under the same amendment was left to wither on the vine. Yet this did not happen because the courts had given Congress a fourteenth amendment power so restricted that no further experiments would have been justified. It happened because, by the time its first efforts had been judicially rejected, Congress was no longer interested in making another try. The HayesTilden Compromise had been accepted, and Congress had gone out of the

tional rights when the states failed in their primary responsibility to do so either by neglecting to enact laws or by refusal or impotence to enforce them.

HarRis, The Quest for EQUality 53 (1960).

If the abolitionist origins of the Fourteenth Amendment are accepted, . . . the states are forbidden to fail to carry out their primary duty of protection; and, when carrying it out, are forbidden to fail to adhere to the standard of equality. Congress is authorized to enforce this provision, that is to say, is authorized to supply the protection of the laws when the states do not, and to correct deviations by the states from the prescribed standard of equality.

tenBroek, The Antislavery Origins of the Fourteenth Amendment 98 (1951). 
civil rights business, which it was not to attempt to re-enter for more than half a century. Indeed, by 1883 some Congressmen may have been only too anxious to give the decisions their modern reading as an excuse for taking no further action. In any case, once that restrictive reading was established, there was no way in which it could be judicially re-examined unless Congress made the challenge by enacting a statute which goes beyond that narrow concept of its powers. We may nevertheless be pardoned for suspecting that the framers of the fourteenth amendment - and even the justices of the 1883 Court would have been far more astonished by the powers later exercised by the judiciary under the fourteenth amendment than by an assertion that that amendment empowers Congress to enact a public accommodations bill, or a statute to punish racially-motivated acts of private intimidation.

In the end, civil rights were largely nationalized after all - and the process of their nationalization is still continuing. Yet this nationalization has taken place in a peculiarly one-sided manner, with the judiciary obliged, at least until the recent legislation, to assume the whole responsibility of defining the new consensus and almost the whole responsibility of enforcing it. The fourteenth amendment was adopted in part to give Congress power to deal with a racial crisis. Yet, in the current racial crisis, there is, according to present theories, almost nothing of major importance which Congress can do - except where it can find power to act in the commerce clause, or some other source independent of the fourteenth amendment.

In view of the fact that an enlargement of federal legislative, rather than judicial, power seems to have been the primary intent, this is an ironic and upside down result. It is also, in my view, an unfortunate one. Piecemeal litigation is hardly an ideal method for the accomplishment of sweeping social reforms. And the civil rights crisis which has precipitated the current legislation certainly indicates that, if further proliferation of lawsuits was ever an adequate answer, it is so no longer. Furthermore, a readjustment of the social, economic, and legal structure so profound that it is being widely referred to as a "revolution" is hardly a process over which the courts should be expected to preside alone and largely unaided, except for an occasional show of force when a court order is openly defied.

Moreover, the presently orthodox theory in effect informs the die-hard white supremacists that, so long as they resist through the forms of law, "state action" is sure to be found, and they remain within the actual or potential orbit of federal power. At the same time, it assures them that, if they act outside the law, then the Constitution commands the federal government to keep hands off and leave them to such sanctions as their friends and sympathizers in state and municipal governments can be persuaded to apply. Thus the orthodox theory is an open invitation to vigilantism. At the same time, the apparent impotence of the national government to define and enforce the newly emerging consensus gives rise, on the other side, to a sense of frustration which can find outlet only in direct action. 
Should Congress ever be minded to enforce the fourteenth amendment by appropriate legislation rather than approaching the problem through the commerce clause, it will be venturing into almost wholly unexplored territory. That territory has not been judicially charted - but neither has it been judicially interdicted. The Congress need not conceive its fourteenth amendment enforcement powers in terms of a narrow and pessimistic reading of a handful of nineteenth century cases - especially since that reading seems only a misreading after all. 